\title{
Kitchen Table Discourse: Negotiating the "Tricky Ground" of Indigenous Research
}

\section{JAY T. JOHNSON}

using aboriginal knowledges protocols and practices rather than western ones is seen by the colonizer set as being problematic our methodologies and protocols are not deemed to be scientific or rigorous or valid they're seen as being primitive second class at best our methodologies don't fit the white rules the house rules dealer's choice and of course our protocols are simply precolumbian how our elders say (though not in so many words) has it come to be that scientific rigor (mortis) has infected this land of our ancestors how have the mis taken assumptions of science come to be privileged over other ways is the scientific method itself not fundamentally flawed an intellectual virus which has become the agent of transmission for western hubris so is perpetuated ad ministratum

-Peter Cole, "trick(ster)s of aboriginal research: or how to use ethical review strategies to perpetuate cultural genocide"

I wish to start this article in search of a middle path; there will be no effort made to hide myself behind some outdated and outmoded convention that pretends a disembodied and objective author/researcher has produced this work. ${ }^{1}$ I free myself from (the myth of) objectivity and follow in the path of feminist and critical researchers by recognizing and identifying my own positionality. ${ }^{2}$ I hope, through writing this article, to build an atmosphere of safety "where I can begin to speak from an integrated place" as an indigenous man and not just as a social scientist "who normally speaks as an objective authority and removes [himself] from the spoken or written word." I seek a middle path through which to traverse the "tricky ground" of indigenous research;

Jay T. Johnson is assistant professor of geography and an affiliate of the Center for Indigenous Nations Studies at the University of Kansas. His research interests comprise areas important to indigenous peoples' self-determination including resource management, international law and cultural politics, as well as the politics and philosophy of place. 
a middle path that will hopefully find "in-between spaces" open to new epistemological pathways, through which new voices and ideas can be heard within the social sciences and, in particular, within geography. This middle path would afford space through which to include my own perspective and acknowledge that I look at the world through a pair of tinted spectacles, but it will more importantly include and acknowledge past and present research companions and friends. ${ }^{4}$ Hopefully I can help create this middle path by incorporating a myriad of voices and narrative forms to show how indigenous geography can move closer to that which it studies. ${ }^{5}$

\section{HOW I CAME TO DO RESEARCH WORK IN AOTEAROA}

This story begins with my own story as a mixed-race Native American, a geographer, and an academic. The story is one about my research work in Aotearoa (New Zealand), what motivated this research, how I have attempted to construct an indigenist methodological framework for this research, and how my own indigenous identity has influenced my research relationships. Because the research I discuss here took place in Aotearoa, I will start (again) by giving a mihimihi or genealogical introduction. ${ }^{6}$ My maternal great-grandmother came from New York and was Seneca (Onodowaga) of the Haudenosaunee. My maternal grandfather came from Ochletree, Kansas, and his mother was Western Cherokee (Tsalagi) and his father was Delaware (Lenni Lenape) from Fall Leaf, Kansas. My paternal grandfather was a Jew from southern Germany. My paternal grandmother was primarily of ScotchIrish ancestry. The Kaw is our river, Kansas is our territory, and Fall Leaf is our town. Placing myself through my whakapapa (genealogy) and identifying my turangawaewae (standing place) is the first crucial step in building a trusting relationship for Māori (as well as for other indigenous peoples) and a critical foundation for knowledge production. ${ }^{7}$ My ancestry and the place I call "home" all play a role in shaping how I view and understand the world. This "internal landscape" shapes me in profound ways and affects my ontological and epistemological frame.

My genealogy and standing place are only part of the "tint" in the spectacles through which I view the world. My academic genealogy, my "disciplining," plays a significant role in coloring the tint of these spectacles too; it brings yet another ontological and epistemological frame through which I attempt to engage the world critically. My academic genealogy is securely founded within the Western tradition and its canon (historical, geographical, and literary): first, a bachelor degree in history, then a master's degree in medical social work (followed by an eight-year career in social work), and finally a doctorate in cultural geography. My decision to pursue a degree in geography was grounded within a desire to understand the struggles of indigenous communities, and I was placed within a discipline that allows for analysis at all scales and across time. 


\section{Postcolonial and Anticolonial Geographies}

As many other indigenous academics have noted, frequently the ontologies and epistemologies in which we were born do not mesh with the ones we discover through our academic work. ${ }^{8}$ At every turn I have tried to find those ideas, within the academy, that will assist me in critically engaging the world and help me to understand better the struggles of indigenous peoples. Occasionally I have been chastised for investigating and employing French philosophers, British geographers, or American anthropologists, as if these engagements make the intellectual goal of investigating indigenous self-determination somehow less indigenous. I respond to this criticism by recognizing that I follow in the footsteps of some of my literary heroines like Audre Lorde or Patricia Grace when I say, "It's not sticking to the old ways that's important. It's being us, using all the new knowledge our way. Everything new belongs to us too." It is our "theft of the masters tools and our reforging of them" that allows us, and those future academics coming behind us, to use and re-reforge them to help in furthering a postcolonial agenda. ${ }^{10}$

I not only firmly agree with Gilmartin and Berg when they state that "postcolonial theory suggests the possibility of a new epistemology within geography" but also agree when they note that "geographers working with postcolonial theories are slow to embrace this possibility."11 I suggest that it is within the burgeoning subfield of indigenous geographies that postcolonial theory has its greatest epistemological impact on the discipline as a whole. ${ }^{12}$ As geographers who work within and for the indigenous world, we are at times furthest from the core of the discipline. Generally, we are allowed to participate from the peripheries, but rarely are we allowed to "set the agenda."13 Being on the peripheries of the discipline can be marginalizing, but it can also be liberating because it is from within these marginal spaces that the evolution of new paradigms becomes possible..$^{14}$ My own research agenda is founded within an anticolonial framework because I am "concerned with breaking, and writing, the silences of the present as well as the past" and privileging indigenous voices in the storytelling inherent in breaking these silences. ${ }^{15}$ I firmly agree with Maivân Lâm when she observes that indigenous voices will play a significant role in re-creating and reenvisioning "the rightful structure, function, and relationship of states to constituent peoples."16

Over the years, I have had the opportunity to attend national and international indigenous gatherings, especially ones focused on issues of health and welfare. Through these gatherings I met other indigenous individuals and groups from across Canada, the United States, Mexico, Thailand, Guatemala, Australia, and Aotearoa, as well as many other parts of the world. Repeatedly through these contacts I have heard discussions that concern the challenges faced by indigenous peoples around the world. I have found, as Moana Jackson states, that there is "certain symmetry" in the challenges faced by indigenous peoples worldwide. ${ }^{17}$ Although there is symmetry to the challenges faced by indigenous peoples, there is also a common interest in finding solutions to these challenges, and this desire is, in large part, what drives these international gatherings. Through participating in these gatherings, and hearing 
the stories told by indigenous peoples from around the world, I realized that various groups were trying approaches to issues of self-determination that were unique to our experiences in the United States. Repeatedly, I heard that one group or another had achieved better outcomes; predominately these success stories focused on the Māori of Aotearoa. I wanted to see for myself if these stories of better outcomes for Māori were true. Instead of researching indigenous failures, a common tactic in the academy, I wanted to research Māori endeavors toward self-determination to determine if they may have successful strategies from which other indigenous communities could learn.

\section{Forging a Middle Path}

As with all research questions, a research plan must be designed, and these plans must traverse "the spaces between research methodologies, ethical principles, institutional regulations, and human subjects as individuals and as socially organized actors and communities," which Linda Tuhiwai Smith has identified as "tricky ground." 18 To navigate this tricky ground I relied on all of those old, new, and reforged tools that I had acquired through my graduate studies and previous career. No matter what tools were chosen for the research plan, I wanted to build my middle path within an "Indigenist research [framework that] focuses on the lived, historical experiences, ideas, traditions, dreams, interests, aspirations, and struggles of Indigenous [peoples]."19

I recognize that the term research is "inextricably linked to European imperialism and colonialism." ${ }^{20}$ Obviously, a thoughtless use of standard research techniques would run the risk of perpetuating European imperialism in a study that hopes to further, rather than diminish, indigenous self-determination. Even within qualitative research frameworks, a colonial discourse of the "other" is maintained when the researcher hides behind the veil of neutrality/ objectivity/subjectivity. ${ }^{21}$ By taking an indigenist focus to this work I tried to "draw upon the traditions - the bodies of knowledge and corresponding codes of values-evolved over many thousands of years by native peoples the world over." 22 I leave behind the myth of neutrality by embracing an indigenist research focus and follow in the path of a critical theorist with "the hope that research could lead to emancipation and social justice for oppressed groups" and recognize that "all positionings (even those of subjugated and oppressed people) are subject to critical interrogation and deconstruction.”23

Many feminist and indigenous academics have written about the imperative to develop reciprocal and respectful relationships in the research endeavor. Russell Bishop describes this development of an ongoing relationship (whakawhanaungatanga) as "the process of establishing whanau (extended family) relationships, literally by means of identifying, through culturally appropriate means, your bodily linkage, your engagement, your connectedness, and, therefore, an unspoken but implicit commitment to other people."24 Building a research relationship, creating a whānau around a shared interest, requires showing your face (he kanohi kitea) to the community, for our somatic engagement is crucial. How can a relationship 
purporting concern over community issues be established through disembodied communications? Bishop goes so far as to contend that establishing and maintaining relationships is more important than any other aspect of the research approach.

\section{Designing a Methodology}

My research into Māori self-determination, which focused on the area of resource management, was guided by three specific methodologies outlined by Smith in Decolonizing Methodologies. ${ }^{25}$ Smith observes that there are various "themes such as cultural survival, self-determination, healing, restoration and social justice [that] are engaging indigenous researchers and indigenous communities in a diverse array of projects." Smith goes on to outline these projects and the methodologies and methods employed toward their fulfillment. My overall aim has been to employee an indigenizing methodology to this research, which, as Smith observes, is "an approach which borrows freely from feminist and critical approaches to research, but privileges indigenous voices."

In an effort to privilege indigenous voices, as well as connect with another methodology presented by Smith, the research focused on critically engaging four specific stories, told by Māori, of their experiences exercising their self-determination over the resources of their communities. As Smith states, "story telling, oral histories, the perspectives of elders and of women have become an integral part of all indigenous research.... These new stories contribute to a collective story in which every indigenous person has a place." 26 The four stories shared with and experienced by me during my research represent only one truth within the "diversity of truths" involved in elaborating the politics of each specific place described. Russell Bishop suggests that "story telling is a useful and culturally appropriate way of representing the 'diversities of truth' within which the story teller rather than the researcher retains control." 27 This is not intended to discount in any way the stories they shared but to observe that different perspectives always govern the way in which one perceives and represents events. Although as the researcher I did not attempt to retain control over the stories as they were told to me, or observed by me, I did have my own experience of the place, the interview, and the interactions of group participants, and these experiences did play a role in how the stories were written.

Sharing is, or at least should be, an integral part of any form of research. Smith observes that one of the most important aspects of indigenous research is "about sharing knowledge between indigenous peoples, around networks and across the world of indigenous peoples." ${ }^{28}$ Beyond the obvious sharing of their stories, many Māori and Pākehā (white New Zealanders) shared generously of their time, knowledge, and hospitality during my research in Aotearoa. I, as an indigenous-identified outsider, was asked on several occasions to share information in two specific ways. First, I was frequently asked what I thought of one or another aspect of Māori self-determination with the idea that an outside observer might have a unique understanding. Second, 
I was asked to share any information I had about other indigenous peoples, particularly my own tribes. Sometimes this request would relate to resource management or land claims, but frequently it was a more general request that demonstrated a desire to know more about my community, our history, and our culture. James Tully envisions this desire for sharing thus: "by listening to the different stories others tell, and giving their own in exchange, the participants come to see their common and interwoven histories together from a multiplicity of paths." 29

One of the driving forces behind engaging in this research has been a desire on my part, spurred by requests from other Native Americans, to learn more about the state of Māori self-determination. As Smith states, "For indigenous researchers sharing is about demystifying knowledge and information and speaking in plain terms to the community." 30 By taking on this research agenda, I have a responsibility to share the information learned not only with the Native American community that spurred my interests in the research but also primarily with the Māori community who agreed to participate in the research. This sharing is a crucial aspect of maintaining the ongoing relationship. By returning their stories, and hearing their feedback, the dialogue continues. There are also obvious issues that concern the protection of intellectual property rights. As research relationships are negotiated, communities may wish to negotiate how, where, and when their stories are shared. This may include final approval over published materials. In some respects this can be the most difficult part of developing a whannau of interest, but if one adopts an indigenist research approach, the goal of indigenous self-determination is implicit.

\section{Negotiating Sharing}

One of my first tasks was to identify those individuals whose stories would be important because this research has been focused on an indigenist approach that privileges indigenous voices. The choice of who to interview for this research was directed initially by contacts provided by my dissertation advisor, Brian Murton, and largely flowed outward from those initial contacts. Early interviews with key Māori academics assisted in establishing further contacts. In addition, the Māori staff and students at the University of Waikato provided invaluable contacts, particularly with those Māori activists most noted in conservation and resource management struggles.

Interviews were conducted in an informal manner in an effort to establish a noninvasive environment for the participants. There were no set questions or rigid formats. The conversations generally followed what Bishop has referred to as a "spiral discourse," which allows participants to follow their own agendas. ${ }^{31}$ My primary aim was to strive for understanding between the individual participants and myself. ${ }^{32}$ I decided to forgo recording equipment in favor of written notes in an effort to make participants feel more at ease and to avoid lengthy discussions about legal releases in group meetings. Following Māori and Native American practices I provided gifts or koha to participants as recognition of their participation and as an acknowledgment 
of the knowledge and hospitality they shared with me. Frequently, interviews would begin on a more formal setting until the koha was presented and I had a chance to introduce myself properly. Following these preliminaries, the interviews generally became more relaxed, and often there was a change of location from a living room or office to a kitchen table. Others have referred to this informal style of communication between indigenous-identified researcher and participant as "kitchen table discourse," 33 the kitchen table being the space in which "insider" communication takes place. ${ }^{34}$ The negotiation of the interview space and the frequent transition from a more formal to a less formal setting, following appropriate protocols, demonstrates how "multiple scales of social relations intersect in the research interview." 35

\section{Inside/Outsider}

My own identification as an indigenous person helped, to some extent, allay concerns that Māori participants may have had about an outsider using their knowledge in an inappropriate manner. In a more recent research project in Aotearoa, a Māori research collaborator took me to meet an important kuia (female elder) to receive her approval. When asked if I could participate in the research project the kuia stated, "well of course, he's Indigenous from 'over there." As someone perceived of as an "insider," I recognize that this carries great responsibility, and that I must remain vigilant in knowing how, when, and where to I share the stories I have been told. I recognize that "their telling might, in some small way, help us to move forward. But, their being told cannot and must not place individuals [and/or communities] at risk." 36

My position as an American Indian-identified researcher presented a unique situation for my research agenda. I was, in some ways, as Smith identifies, an "inside/outsider." Although not the classic outside, "objective" researcher "able to observe without being implicated in the scene," I am outside the dualistic relationship between Māori and Pākehā. And although indigenous identified, I am not a Māori who owes specific allegiances to whanau, hapu, or iwi. Feminist and critical approaches to research have created an increased acceptability for an "insider" approach within qualitative research, but, as Smith observes, "indigenous research approaches problematize the insider model in different ways because there are multiple ways of both being an insider and an outsider in indigenous contexts." 37 In many contexts within my research in Aotearoa I was treated, if not as an insider, at least as an indigenous individual who would understand the broader issues and impacts of colonialism on indigenous communities. As an outsider, although I did understand the broad context of how Māori had been affected by colonialism, there was much I needed to learn about the specific situations and locations in which their struggles have been lived. The learning curve of an outsider, as well as the occasional acceptance as an insider, is contained within the stories I gathered. 


\section{CONCLUSIONS}

Although the methodology I have laid out in this article has been focused around the stories and voices of the Māori I have worked with during and since my dissertation research, I have chosen not to share their stories, which are available elsewhere. ${ }^{38}$ Instead I will reflect on my successes and failures in negotiating the tricky ground of indigenous research. As I stated previously, my search has been for a middle path through which to negotiate space for as much inclusion as can be accommodated within (and pushing the limits of) academic research and writing. This inclusion has focused on bringing the stories of my research partners into the written work. The inclusion sought has also been concerned with recognizing the myth of the objective researcher, which allows me to show and describe myself as a "situated researcher," somatically engaged with my research whänau. Thankfully, one of my significant successes has been my ability to create and maintain what I hope will be lifelong connections with several Māori who started out as research partners. There have been mistakes along the way as well.

The "disciplining" process one encounters in graduate school has the unfortunate side effect of creating a certain amount of arrogance, and I was not immune to this influence. At every stage in my research process I felt that I had learned enough to proceed to the next stage, and at every stage I was forced to realize that there was an immense amount yet to be learned, hopefully not an uncommon experience in the research process. Fiona Cram translates the Māori cultural value identified by Smith, kaua e mahaki, as "Do not flaunt your knowledge. This is about finding ways to share knowledge, to be generous with knowledge without being a 'show-off' or being arrogant." 39 Generally I discovered my own ignorance and arrogance through selfreflection, but occasionally research partners have confronted me with my arrogance. When one introduces himself or herself to a potential indigenous research partner, any hint of arrogance will be addressed in some fashion. If you are lucky, the potential research partner will only joke with or chastise you. If you are unlucky, your first encounter may be your last.

Although I have learned a significant amount about Māori tikanga (law/ customs), I will never be an "expert." Despite how the academy situates the ethnographer, or cultural geographer, as an "expert" in another culture, the reality is that only the autoethnographer (those writing from within their own culture to a metropolitan audience) can ever really claim expert status. ${ }^{40}$ Some indigenous academics have decided that this limitation justifies allowing only indigenous academics to conduct research in their own communities, if research is to happen at all. Others have recognized that the work of certain nonindigenous researchers has provided significant support to the social justice efforts of indigenous peoples, particularly when these nonindigenous researchers, through their research work, mentor indigenous students and scholars. ${ }^{41}$ We all must remember how important it is to keep our arrogance in check and to resist the "expert" title when working with cultures other than our own.

Hopefully my own story of working as an indigenous inside/outsider has provided some insights that will be useful to others in negotiating their 
own middle path through the sometimes treacherous ground of indigenous research. Perhaps this single quote by Linda Tuhiwai Smith best sums up negotiating the tricky ground of doing research with indigenous communities: "For indigenous and other marginalized communities research ethics is at a very basic level about establishing, maintaining, and nurturing reciprocal and respectful relationships, not just among people as individuals but also with people as individuals, as collectives, and as members of communities, and with humans who live in and with other entities in the environment." 42

\section{Acknowledgments}

I would like to acknowledge those who have shared their stories with me and helped me to know when I was being arrogant, especially Mere Roberts, Angeline Greensill, Helen Hayward, and Paeata Clark. For his specific encouragement to discuss my research experience and methodological quandaries, I want to thank Geoff White of the University of Hawai'i.

\section{NOTES}

1. Linda Tuhiwai Smith, "On Tricky Ground: Researching the Native in the Age of Uncertainty," in The SAGE Handbook of Qualitative Research, ed. Norman K. Denzin and Yvonna S. Lincoln (Thousand Oaks, CA: Sage Publications, 2005), 85-107.

"Objectivity, 'that pathology of cognition that entails silence about the speaker, about [his or her] interests and [his or her] desires, and how these are socially situated and structurally maintained' is a denial of identity." Alvin W. Gouldner, "The Dark Side of the Dialectic: Toward a New Objectivity," Sociological Inquiry 46, no. 1 (1976): 32, quoted in Russell Bishop, "Freeing Ourselves from Neocolonial Domination in Research: A Kaupapa Māori Approach to Creating Knowledge," The SAGE Handbook of Qualitative Research, 129.

2. See, e.g., Lous Heshusius, "Freeing Ourselves from Objectivity: Managing Subjectivity or Turning toward a Participatory Mode of Consciousness?" Educational Researcher 23, no. 3 (1994): 15-22; Mary Gilmartin, "Making Space for Personal Journeys," in Feminist Geography in Practice: Research and Methods, ed. Pamela Moss (Oxford and Malden, MA: Blackwell Publishers, 2002), 31-42; C. Katz, "All the World Is Staged: Intellectuals and the Projects of Ethnography," Environment and Planning D: Society and Space 10 (1992): 495-510; Linda Tuhiwai Smith, Decolonizing Methodologies: Research and Indigenous Peoples (London: Zed Books, 1999).

3. Lillian E. Dyck, "An Analysis of Western, Feminist and Aboriginal Science Using the Medicine Wheel of the Plains Indians," in As We See-: Aboriginal Pedagogy, ed. Lenore A. Stiffarm (Saskatoon: University of Saskatchewan, 1998), 87.

4. R. T. Harrison and D. N. Livingstone, "Philosophy and Problems in Human Geography: A Presuppositional Approach,” Area 12 (1980): 26.

5. Greg Sarris, Keeping Slug Woman Alive: A Holistic Approach to American Indian Texts (Berkeley: University of California Press, 1993), 7.

6. "For example, a mihimihi (formal ritualized introduction) at a hui (Māori ceremonial gathering) involves stating your own whakapapa in order to establish relationships with the hosts/others/visitors. ... [A] mihimihi is a statement of where you 
are from and of how you can be related and connected to these other people and the land, in both the past and the present." Quoted in Bishop, "Freeing Ourselves from Neocolonial Domination in Research,"118.

7. David Turnbull, Masons, Tricksters, and Cartographers: Comparative Studies in the Sociology of Scientific and Indigenous Knowledge (Amsterdam: Harwood Academic, 2000).

8. See, e.g., Renee Pualani Louis, "Indigenous Hawaiian Cartographer: In Search of Common Ground,” Cartographic Perspectives 48 (Spring 2004): 7-23.

9. Patricia Grace, Cousins (Honolulu: University of Hawai'i Press, 1998), 235.

10. Janice Radway, "Mail-Order Culture and Its Critics: The Book-of-the-Month Club, Commodification and Consumption, and the Problem of Cultural Authority," in Cultural Studies, ed. Lawrence Grossberg, Cary Nelson, and Paula A. Treichler (New York: Routledge, 1992), 527.

11. Mary Gilmartin and Lawrence D. Berg, "Locating Postcolonialism," Area 39, no. 1 (2007): 123.

12. For a discussion of indigenous geographies refer to José Barreiro, "Indigenous Geographyas Discipline Arrives," Indian County Today (2004), http:/ / www.indiancountry. com/content.cfm?id=1096409838 (accessed 20 April 2005); Jay T. Johnson, Garth Cant, Richard Howitt, and Evelyn Peters, "Creating Anti-colonial Geographies: Embracing Indigenous Peoples Knowledges and Rights,” Geographical Research 45, no. 2 (2007): 117-20; Wendy S. Shaw, R. D. K. Herman, and G. Rebecca Dobbs, "Encountering Indigeneity: Re-imagining and Decolonizing Geography," Geografiska Annaler, Series B: Human Geography 88, no. 3 (2006): 267-76.

13. Gilmartin and Berg, "Locating Postcolonialism," 121-22.

14. See, e.g., Gloria Anzaldua, Borderlands/La Frontera (San Francisco: Spinster/ Aunt Lute Press, 1987); Bell Hooks, "Choosing the Margin as a Space of Radical Openness," in Yearning, ed. Bell Hooks (Boston: South End Press, 1990), 145-55.

15. Gilmartin, "Making Space for Personal Journeys," 35.

16. Maivân Clech Lâm, At the Edge of the State: Indigenous Peoples and SelfDetermination (Ardsley, NY: Transnational Publishers, 2000), xxvi.

17. Moana Jackson, "The Nature of Knowing: Self-Determination, Land and the Double Helix." Paper presented at Indigenous Peoples, Environment, and Development Conference, Zurich, Switzerland, 15-18 May 1995.

18. Smith, "On Tricky Ground," 85.

19. Lester-Irabinna Rigney, "Internationalization of an Indigenous Anticolonial Cultural Critique of Research Methodologies: A Guide to Indigenist Research Methodology and Its Principles," Wicazo Sa Review 14, no. 2 (1999): 117.

20. Smith, Decolonizing Methodologies, 1.

21. Bishop, "Freeing Ourselves from Neocolonial Domination in Research," 129.

22. Ward Churchill, "I Am Indigenist," in Struggle for the Land, ed. Ward Churchill (Monroe, ME: Common Courage Press, 1993), 403.

23. Smith, "On Tricky Ground," 88.

24. Katz, "All the World Is Staged," 505; Bishop, "Freeing Ourselves from Neocolonial Domination in Research," 118.

25. Smith, Decolonizing Methodologies, 142-62.

26. Ibid., 144. 
27. Russell Bishop, Collaborative Research Stories: Whakawhanaungatanga (Palmerston North, NZ: Dunmore Press, 1999), 24, quoted in Smith, Decolonizing Methodologies, 145.

28. Smith, Decolonizing Methodologies, 160.

29. James Tully, Strange Multiplicity: Constitutionalism in an Age of Diversity (New York: Cambridge University Press, 1995), 25-26.

30. Smith, Decolonizing Methodologies, 161.

31. Bishop, "Freeing Ourselves from Neocolonial Domination in Research," $109-37$.

32. Ibid., 125.

33. Holly YoungBear-Tibbetts, "The Struggle to Preserve Turangawaewae: Symbolic Discourse of Māori Political Activism” (PhD diss., University of Wisconsin, 1996).

34. Toni C. King et al., "Andrea's Third Shift: The Invisible Work of AfricanAmerican Women in Higher Education," in This Bridge We Call Home: Radical Visions for Transformation, ed. Gloria Anzaldúa and AnaLouise Keating (New York: Routledge, 2002), 403-14.

35. Sarah A. Elwood and Deborah G. Martin, "'Placing' Interviews: Location and Scales of Power in Qualitative Research," The Professional Geographer 52, no. 4 (2000): 649 .

36. Ardra L. Cole, “Telling 'Inside' Stories: The Paradox of Researcher Privilege," in Lives in Context: The Art of Life History Research, ed. Ardra L. Cole and J. Gary Knowles (Walnut Creek, CA: AltaMira Press, 2001), 168.

37. Smith, Decolonizing Methodologies, 137.

38. Jay T. Johnson, "Biculturalism, Resource Management and Indigenous Selfdetermination” (PhD diss., University of Hawai'i at Mānoa, 2003); Jay T. Johnson, "Indigenous Resource Management and Treaty Partnership: Aotearoa/New Zealand and Nunavut Territory, Canada," in Windows on a Changing World: NZGS Conference 2003, ed. Jay Gao, Richard Le Heron, and June Logie (Auckland: New Zealand Geographical Society, 2003), 101-6; Jay T. Johnson, "Indigeneity's Challenges to the White Settler-State: Creating a Thirdspace for Dynamic Citizenship," Alternatives: Global, Local, Political 33, no. 1 (2008): 29-52.

39. Fiona Cram, "Rangahau Māori; Tona tika, tona pono-The Validity and Integrity of Māori Research," in Research Ethics in Aotearoa New Zealand Concepts, Practice, Critique, ed. Martin Tolich (Auckland: Pearson Education New Zealand, 2001), 35-52, quoted in Smith, "On Tricky Ground," 98.

40. Mary Louise Pratt, Imperial Eyes: Travel Writing and Transculturation (London and New York: Routledge, 1992); David Butz and Kathryn Besio, "The Value of Autoethnography for Field Research in Transcultural Settings," The Professional Geographer 56, no. 3 (2004): 350-60.

41. Smith, Decolonizing Methodologies, 175.

42. Smith, "On Tricky Ground," 97. 
